\title{
Celiac Disease and Gluten-free Diet in Portuguese Children - An Anthropometric Marker Contribution Assessment
}

\author{
Patrícia Soares ${ }^{1}$, Piedade Sande Lemos ${ }^{2}$, Ana Maria Pires ${ }^{1,3}$, Ana Cláudia Cavaco de Sousa ${ }^{1, *}$ \\ ${ }^{1}$ Universidade Atlântica - Centro de Estudos, Sociedade, Organizações e Bem-Estar (CESOB) \\ ${ }^{2}$ Nova Medical School, Hospital Amadora-Sintra, Hospital CUF-Cascais \\ ${ }^{3}$ Faculdade de Ciências da Universidade de Lisboa - Centre for Ecology, Evolution and Environmental Changes (cE3c) \\ *Corresponding author: asousa@uatlantica.pt
}

\begin{abstract}
Celiac disease is an autoimmune disease that is expressed by chronic food sensitivity to gluten, having as typical symptoms diarrhea and weight loss. The present study has evaluated anthropometric marker progressions in 61 Portuguese children with celiac disease, at diagnosis time and at the study time, comparing these variations with the intake of gluten free products. Data from 61 children $(59.0 \%$ girls) with celiac disease were evaluated, following a gluten free diet for $5.0 \pm 4.6$ years. Statistical $t$-test analysis of pBMI at diagnosis and at study time, revealed a positive increase with statistical significance for both girls and boys $(p=0.008)$. The differences between ingested and recommended values were quantified and confirming the increase in total energy consumption and carbohydrates. Following a gluten free diet allows the recovery of the nutritional status in most children; however, nutritional counseling seems mandatory to avoid nutrient imbalances and further health issues.
\end{abstract}

Keywords: celiac disease, gluten free diet, children, natural gluten free products, processed gluten free products

Cite This Article: Patrícia Soares, Piedade Sande Lemos, Ana Maria Pires, and Ana Cláudia Cavaco de Sousa, "Celiac Disease and Gluten-free Diet in Portuguese Children - An Anthropometric Marker Contribution Assessment." International Journal of Celiac Disease, vol. 5, no. 2 (2017): 62-68. doi: 10.12691/ijcd-5-2-5.

\section{Introduction}

Celiac disease (CD) is an autoimmune disease characterized by chronic food gluten sensitivity in genetically susceptible individuals [1]. Comparing it with various autoimmune diseases, CD presents the highest number of new cases [2].

Despite the incidence of $\mathrm{CD}$ have increased significantly over the last 60 years [3], doesn't display a common pattern around the world for multiple reasons. In Europe it occurs in approximately $1.0 \%$ of the population $[4,5,6]$ with incidence in Finland and Sweden as high as $2.0 \%$ to $3.0 \%$ [7] and in Portugal mainland about $0.7 \%$ $[8,9]$. However, only $0.07 \%$ were found for under 18 in Madeira Island [10]. Yet, those Portuguese values can be higher due to atypical and asymptomatic forms that are underdiagnosed and absence of more recent data, that include information on diagnosis based in heterogeneous clinical presentation of the disease. [11].

The epidemiology and phenotype of CD are constantly changing, whereas the symptoms exhibited by children with $\mathrm{CD}$ are variable and influenced by age. Despite being associated with children with reduced nutrient absorption, recent studies have shown that obese children have been diagnosed with gluten sensitive enteropathy [12]. Very young children, have mostly classic symptoms such as: diarrhea, abdominal distension and growth retardation
[13], while school-aged children and adolescents present mostly atypical gastrointestinal symptoms: cramping, vomiting and constipation [14]. Other extra-intestinal conditions that can be associated with the diagnosis include arthritis, neurological disorders and anemia $[15,16,17]$.

Gluten-free diet (GFD) is the only current treatment for this condition that allows the recovery of the intestine and the gradual decrease of digestive symptoms, signs and systemic manifestations $[18,19,20]$. Several authors described difficulties to follow a strict GFD and indicate factors as taste, scarcity, cost and insufficient labeling of products. Also, the difficulty in eating out and limited knowledge of general community contribute to a negative impact on quality of life patients leading to low compliance, particularly in adolescence [21-27].

Gluten-free foods can be categorized as natural (rice, maize, potato), and processed gluten free foods (wheat, barley). For rye and oat, immunotoxicity is not totally excluded since their storage proteins, secalin and avenin respectively, have also multiple proline and glutamine residues making them resistant to gastrointestinal digestion and increase tissue transglutaminase activity $[28,29]$.

Gluten removal process can also lead to a change in the overall composition of nutrients. In the last decade, the industry has placed in the market a large diversity of foods specifically designed for gluten-free diets, providing greater choice and also an increased intake of these foods 
(nutritionally altered). On the other hand, the increased intestinal permeability induced by the industrial food additives, explains the observed surge in general autoimmune diseases, CD included [30]. However, and parallel to the beneficial effect already described, the nutritional adequacy of GFD and the impact on anthropometric parameters of children with $\mathrm{CD}$, has been questioned [31], since it may lead to nutritional imbalances, increasing the shortcomings caused by the intestinal malabsorption [32].

Evaluations of children's anthropometric data evolution with CD has been studied and in some cases, children with normal weight at the time of diagnosis evolve to a state of pre-obesity or obesity during follow-up of GFD $[11,12,33,34,35,36]$. Despite the relevance of this subject, there is insufficient monitoring and scarce published data for the anthropometric evolution of CD Portuguese children, reinforcing the adequacy and necessity of the present study. For this purpose an evaluation of anthropometric marker progressions in Portuguese CD children was performed, followed by a comparative study between their food nutrient intake and the recommendations from the Portuguese National Health Institute. The proportion of specially designed gluten free products versus naturally gluten free foods in the food intake of these children was also evaluated.

\section{Methods}

The present study is a descriptive, observational, crosssectional evaluation of anthropometric marker progressions in Portuguese children with $\mathrm{CD}$, based on survey research methodology. The development and implementation of a survey questionnaire followed guidelines for this research methodology $[37,38,39]$. The questions were ordered to establish both the survey's logic and inner flow. A widespread dissemination was done by the Portuguese Celiac Association webpage ensuring answers from parents or caregivers of children with CD. Data collection took place between February and April 2015.

Inclusion criteria were being older than five years old, compliance with GFD after a comproved diagnosis by one or more of the following methods: serological tests, human leukocyte antigen typing, video capsule endoscopy and small intestinal biopsy. Sixty-three completed questionnaires were obtained, of which two were excluded, because they did not meet the inclusion criteria.

Body Mass Index (BMI) was calculated as weight $(\mathrm{kg}) /$ [height $(\mathrm{m})]^{2}$ and used self-reported weight and height. Body mass index percentiles (pBMI) were estimated using growth curves adopted by the Health General Directorate [40] as recommended by National Centre for Health and Statistics.

For processed free gluten food, energy and macronutrients values were estimated from their labels, while for natural free gluten food the Portuguese Food Composition Table was used [41]. Energy and macronutrient recommendations were available at the Portuguese Platform Against Obesity [42,43,44]. The relative difference between the recommended and the ingested value was given in percentage.

Respecting the principles of the Helsinki Declaration, this study was approved by the Ethics Committee of the Atlântica University and informed consent obtained from participants at the time of completing the questionnaire.

Statistical analysis was performed using Excel, Microsoft Office 2010 (Microsoft, USA). The numerical variables were presented as mean and standard deviation. Categorical variables were expressed as a percentage. The parametric Student t-tailed test was used to analyze the difference between the average pBMI paired data at diagnosis and study time as well as for the intake differences between boys and girls. The non-parametric sign test [45] was used to counts signs, positive (if above) and negative (if below), of the determined values for energy intake and macronutrient compared with the recommendations from the Portuguese National Health Institute for children of the same age in the $50^{\text {th }}$ percentile of the body mass index (hypothesized value). The null hypothesis will be rejected when the numbers of positive and negative signs differ significantly from equality. The critical $p$ value was set at 0.05 according to the confidence interval of $95 \%$.

\section{Results}

Children were positively diagnosed for $\mathrm{CD}$ mainly through intestinal biopsy $(80.3 \%)$ and the remaining through serological tests according to ESPGHAN guidelines from 2012; antitransglutaminase antibodies ( $>10$ times upper limit) and antiendomysial antibodies positive [46]. Coexisting immunological conditions were also reported for about $28 \%$ of children $(25 \%$ girls and $32 \%$ boys), such as dermatitis (5\%), lactose intolerance $(7 \%)$ and respiratory problems $(13 \%)$.

Descriptive statistics for demographic variables showed participants being $5.1 \pm 3.8$ years at $\mathrm{CD}$ diagnosis and $10.0 \pm 3.7$ years at study time, where $59.0 \%$ were girls and $41.0 \%$ boys. In average participants showed $5.0 \pm 4.6$ years of GFD (Table 1).

Table 1. Characteristics of gluten-free diet survey participants $(n=61)$

\begin{tabular}{|c|c|c|c|c|c|c|}
\hline & \multicolumn{2}{|c|}{$\begin{array}{c}\text { Girls } \\
(\mathrm{n}=36 ; 59.0 \%)\end{array}$} & \multicolumn{2}{|c|}{$\begin{array}{c}\text { Boys } \\
(\mathrm{n}=25 ; 41.0 \%)\end{array}$} & \multicolumn{2}{|c|}{$\begin{array}{c}\text { Total } \\
(n=61)\end{array}$} \\
\hline & Mean $\pm s d$ & Range & Mean \pm sd & Range & Mean \pm sd & Range \\
\hline Age at diagnosis & $5.7 \pm 4.4$ & $2-16$ & $4.2 \pm 2.5$ & $2-10$ & $5.1 \pm 3.8$ & $2-16$ \\
\hline Age at study time & $10.3 \pm 3.8$ & $2-18$ & $9.6 \pm 3.6$ & $4-16$ & $10.0 \pm 3.7$ & $2-18$ \\
\hline Years of gluten-free diet & $4.8 \pm 4.4$ & $0-10$ & $5.4 \pm 4.8$ & $1-14$ & $5.0 \pm 4.6$ & $0-14$ \\
\hline
\end{tabular}




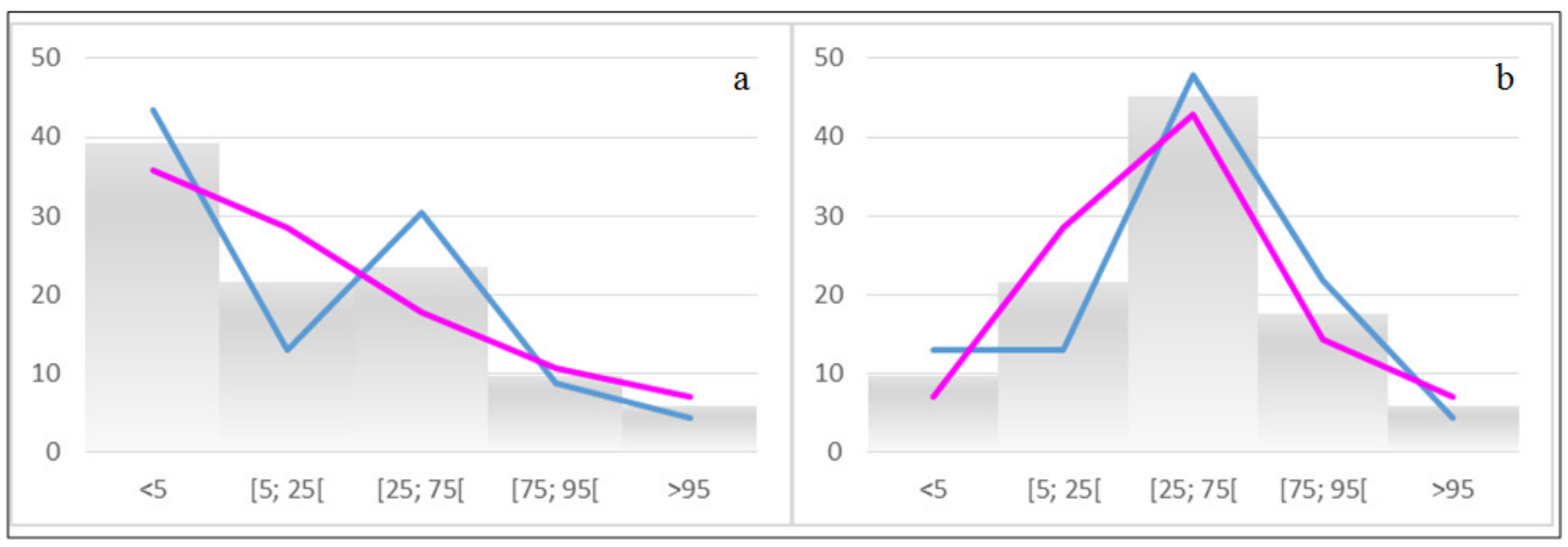

Figure 1. Pattern of pBMI classes for evaluated children at diagnosis (a) and at study time (b) $\square$ all $\square$ girls $\square$ boys

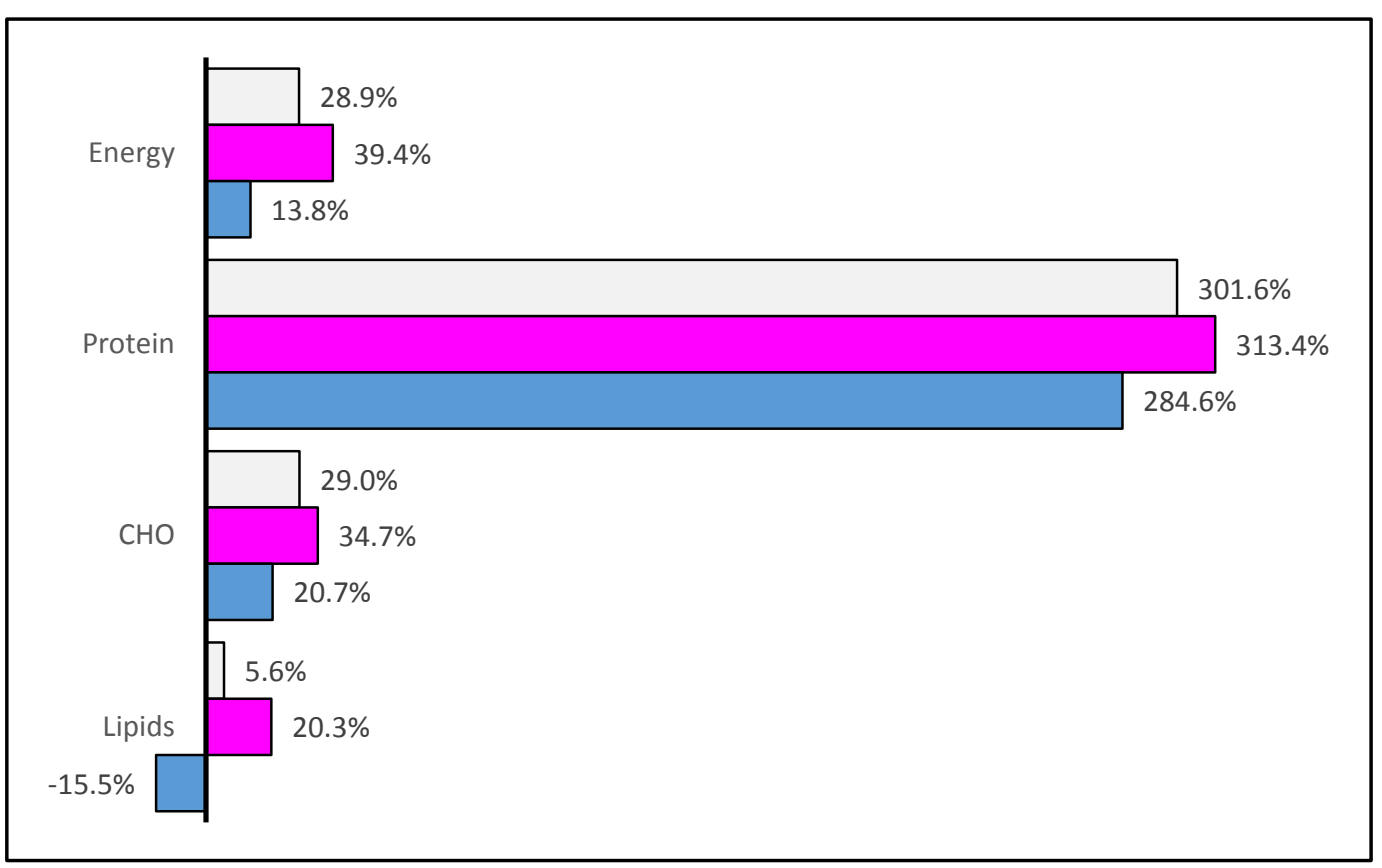

Figure 2. Deflect percentage from the recommended values of macronutrients intake for all children, boys and girls, $\square$ all $\square$ girls $\square$ boys

As showed in Figure 1, almost $40 \%$ of children were underweight at diagnosis (pBMI $<5$ ), $10 \%$ overweight and $6.0 \%$ were obese; whereas at study time only $10 \%$ of children exhibit a pBMI $<5$. The analysis of the figure showed a clear recover of the pBMI pattern after following a GFD, for both boys and girls. The constant percentage of obese cases together with a considerable increase in overweight values, contributes to an increase of total number of children with pBMI above normal.

Statistical $t$-test analysis of pBMI at diagnosis and at study time, revealed a statistical significant increase for girls and boys $(\mathrm{p}=0.008)$. Although a positive trend was revealed for both genders when analyzed separately, the statistical significance was only observed for girl's data ( $p$ $=0.049$ ).

The sign test allocated either positive or negative sign to each observation, according to whether is it higher or lower than those recommended for children of the same age (pBMI of $50 \%$ ). Sampled children revealed values above those recommended for energy intake $(p=0.007)$ and carbohydrates $(\mathrm{p}=0.007)$. Regarding proteins ingested, all children showed values much higher than those recommended $(\mathrm{p}=0.000)$. The fat intake results were not statistically significant $(p=1.101)$, as a matter of fact boys presented a lipids consume below the recommended.

The differences between ingested and recommended values were quantified and are showed in Figure 2. Despite confirming the increase in total energy consumption and carbohydrates, these values are not so surprising as those observed for protein consumption and for the unexpected negative value for lipid intake observed in boys.

The natural gluten free products as fruits, dairy products, soup and vegetables presented the higher frequency intake, once or twice a day. Regarding, specially designed gluten free products, bread is the most consumed while products also considered as harm food (pre-prepared meals, salty snacks, desserts...) were those that were consumed in less quantity (Figure 3). However, weighted analysis of nutrient proportion for specially designed gluten free products revealed that an important part of daily energy intake $(40.9 \%)$ become from unnatural source (Table 2.). Also $50 \%$ of daily carbohydrate intake comes from processed products. This patter was common for girls and boys. 


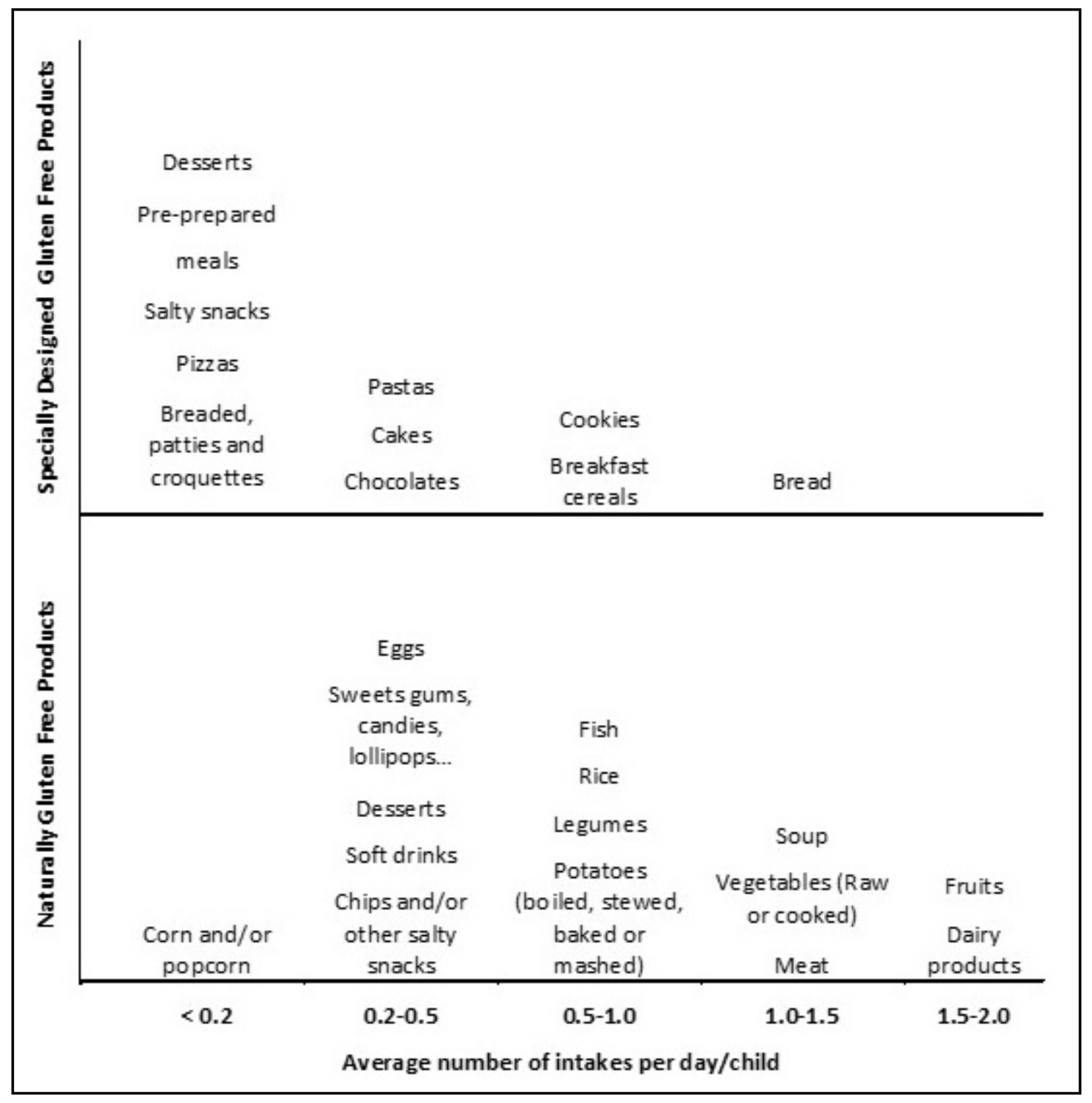

Figure 3. Intake frequency of naturally and specially designed gluten free products

Table 2. Percentage diet intake macronutrients for boys and girls of specially designed gluten free products

\begin{tabular}{|l|c|c|c|c|}
\cline { 2 - 5 } \multicolumn{1}{c|}{} & Energy & Protein & CHO & Lipids \\
\hline Girls & $39.8 \%$ & $30.7 \%$ & $52.0 \%$ & $23.4 \%$ \\
\hline Boys & $43.8 \%$ & $30.3 \%$ & $58.6 \%$ & $29.1 \%$ \\
\hline Total & $40.9 \%$ & $30.1 \%$ & $54.1 \%$ & $28.0 \%$ \\
\hline
\end{tabular}

\section{Discussion}

Data were obtained with the support of the Portuguese Celiac Association and reveals a higher incidence of CD in girls, but far from the value presented by reference [47] and reference [48], which reflects the fact that twice as many girls than boys are diagnosed with CD. As well as Lerner et al. [2] that associated a high frequency of CD linked with other autoimmune pathologies, also this study revealed high percentages of several autoimmune diseases associated with CD. Nonetheless, these values are not associated with children with low weight. It is generally accepted that GFD provides the decrease of systemic symptoms and patient's weight recover [18,49,50,51]. However, the nutritional adequacy of this diet has been questioned, mainly because there is conflict data regarding anthropometric parameters for children with $\mathrm{CD}$ $[11,32,33,34,35,36]$.

The present study results reinforce that the GFD is favorable for the recovery of diagnosed children, once the nutritional status (pBMI) evolved positively with a slight increase in the number of overweight obese children. These values highly contracts with reference [11] results that showed overweight children frequency with $\mathrm{CD}$ nearly doubling after one year of GFD. With a similar study design, reference [33] obtained similar results for Italian children with CD. A decrease in individual's number with low weight was obtained such as a minimum increase in the number of individuals with overweight. Also, Reilly et al. [52] observed a BMI decrease and an increase of overweight and obese in American children. Reference [12] recently showed a weight improvement of children with $\mathrm{CD}$ who were overweighed or obese at diagnosis. All these studies highlight the risk of following a GFD without adequate information that is essential for a careful food choice.

There is a trend that shows an increase in consumption of all macronutrients and consequently of total energy intake (Figure 2). This pattern is also present in several 
studies that refer the GFD to be associated with high protein and lipid intake $[32,53,54,55,56]$. However, this imbalance cannot be consider only for CD children, since exits a large difference between the nutritional recommendations and the actual consumption of protein reported for general population. The unexpected negative value for the relative percentage of boy's lipid intake observed is not in agreement with general literature and probably could be a specificity of the analyzed sample.

The percentage of macronutrients in daily intake followed the pattern between the different studies for energy, protein, carbohydrate and lipids, 40.9\%, 30.1\%; $54.1 \%$, 28.0\%, respectively (Table 2.). However, it is in contrast with reference [49] research, where the intake of energy and nutrients were evaluated for children of the same age with and without CD (following diet with gluten) and was found that thirteen of twenty-five children (52\%) did not reach the energy intake recommendations.

Despite the availability of many natural gluten free products, the lack of adequate information and the media disclosure of processed products, also gluten free, promote a general inflated demand and consumption of the latter ones. These situation leads to an increase of processed food consumption and frequently nutrients imbalance diet $[57,58,59,60,61]$. However, foods with lower frequency intake are associated with the term "fast food" and as such, are regarded as being harmful. In this specific population the concern with diet is certainly more common what is demonstrated by the strong choice of natural gluten free products (Figure 3). Another important and positive aspect was the ingestion of soup and vegetables, fruit and dairy products once or twice a day. Regarding maize, a natural gluten free product with an easy access and inexpensive, it was not much consumed, with the exception of corn bread, perhaps because it is not common in the Mediterranean diet. These adjustments are of enhanced importance, not only because nutritional balance but also because gluten-free products are more expensive than equivalents with gluten, adding costs for families [62].

\section{Conclusion}

This weight dynamic study strengthens that following a GFD the proper anthropometric values can be established. However, any restrictive diet is inherently at risk of nutritional inadequacy and therefore the publicizing, information dissemination and specialized monitoring of CD children are mandatory.

The existence of many naturally gluten free products should be taken into account, even if some Mediterranean habits must change by helping these children and their families in the choice of good food options to avoid shortages or nutritional excesses. For example, inclusion of cassava, amaranth, buckwheat and maize promotion could be a good strategy for all stakeholders.

Furthermore, all health professionals leading diagnosis must remain vigilant and invest in their own training since knowledge about symptoms, diagnosis and anthropometric marker are in constant evolution. The strength of our study lies in the fact that this is an important contribution for anthropometric markers in Portuguese children's with CD. This topic has been receiving a lot of attention from de
Associação Portuguesa de Celíacos in attempt to spread scientific information around members, their families and general interested public. However, exist low confidence that the evidence reflects the true effect of GFD in BMI since it was achieved with a reduced sample.

\section{Acknowledgements}

The authors thank all parents who accepted to participate on this study with their children's information. Thanks are also due to Associação Portuguesa de Celíacos for help and availability. This work was CESOB. F. Bonacho kindly reviewed an early version of this manuscript.

\section{References}

[1] Bai JC, Fried M, Corazza GR, Schuppan D, Farthing M, Catassi C Greco L, Cohen H, Ciacci C, Eliakim R, Fasano A, González A, Krabshuis JH, LeMair A. World Gastroenterology Organisation global guidelines on celiac disease. Journal of Clinical Gastroenterology. 2013; 47(2): 121-6.

[2] Lerner A, Jeremias P, Matthias T. The World Incidence and Prevalence of Autoimmune Diseases is Increasing. International Journal of Celiac Disease. 2015; 3(4): 151-155.

[3] Lerner A, Jeremias P, Matthias T. The World Incidence of Celiac Disease in Increasing: a Review. International Journal of Recent Scientific Research. 2015; 7 (7): 5491-5496.

[4] Hoffenberg EJ, MacKenzie T, Barriga KJ, Eisenbarth GS, Bao F, Haas JE, Erlich H, Bugawan TI, Sokol RJ, Taki I, Norris JM, Rewars M. A prospective study of the incidence og childhood celiac disease. Journal Pediatrics. 2003; 143: 308-314

[5] Tack GJ, Verbeek WHM, Schreurs MWJ, Mulder CJJ. The spectrum of celiac disease: epidemiology, clinical aspects and treatment. Nature Reviews Gastroenterology and Hepatology. 2010; 7: 204-213.

[6] Catassi C, Gatti S, Fasano A. The new epidemiology of celiac disease. Journal of Pediatric Gastroenterology and Nutrition. 2014; 59(Suppl 1): S7-9.

[7] Myléus A, Ivarsson A, Webb C, Danielsson L, Hernell O, Högberg L, Karlsson E, Lagerqvist C, Norström F, Rosén A, Sandström O, Stenhammar J, Stenlund H, Wall S, Carlsson A. Celiac disease revealed in $3 \%$ of Swedish 12-years-orld born during an epidemic. Journal of Pediatrics Gastroenterology Nutrition. 2009; 49: 170-176.

[8] Antunes H. First study on the prevalence of celiac disease in a Portuguese population. Journal Pediatrics of Gastroenterology Nutrition. 2002; 34: 240.

[9] Antunes H, Abreu I, Nogueiras A, Sá C, Gonçalves C, Cleto P, Garcia F, Alves Adelaide, Lemos D. Primeira Determinação de Prevalência de Doença Celíaca numa População Portuguesa [First Prevalence of Celiac Disease in a Portuguese Population]. Acta Médica Portuguesa. 2006; 19: 115-20.

[10] Oliveira JRH, Cabral AJ, Ferreira E, Capelinha F, Spínola H, Gonçalves R. Celiac disease in children from Madeira Island and its prevalence in first degree relatives. Arquives of Gastroenterology. 2014; 51(2): 151-154.

[11] Valletta E, Fornaro M, Cipolli M, Conte S, Bissolo F, Danchielli C. Celiac disease and obesity: need for nutritional follow-up after diagnosis. European Journal of Clinical Nutrition. 2010; 64(11): 1371-1372.

[12] Livshits OE, Shaoul R, Reifen R, Matthias T, Lerner A. Can Celiac Disease Present Along With Childhood Obesity? International Journal of Celiac Disease. 2017; 5(1): 19-23.

[13] Telega G, Bennet TR, Werlin S. Emerging new clinical patterns in the presentation of celiac disease. Archives of Pediatrics \& Adolescent Medicine. 2008; 162(2): 164-168.

[14] Aurangzeb B, Leach ST, Lemberg DA, Day AS. Nutritional status of children with coeliac disease. Acta Pediatrica: 2010; 99: 1020-25. 
[15] Hernandez L, Green PH. Extraintestinal manifestations of celiac disease. Current Gastroenterology Reports. 2006; 8(5): 383-9.

[16] Balamtekin N, Uslu N, Baysoy G, Usta Y, Demir H, SaltikTemizel IN, Ozen H, Gürakan F, Yüce A. The presentation of celiac disease in 220 Turkish children. The Turkish Journal of Pediatrics. 2010; 52(3): 239-44.

[17] Lerner A, Matthias T. Extra Intestinal Manifestations of CD: Common Pathways in the Gut-remote Organs' Axes. International Journal of Celiac Disease. 2017; 5(1): 1-5.

[18] Castillo NE, Theethira TG, Leffler DA. The present and the future in the diagnosis and management of celiac disease. Gastroenterology Report. 2015; 3(1): 3-11.

[19] Bascuñán, KA, Vespa MC, Araya M. Celiac disease: understanding the gluten-free diet. European Journal of Nutrition: 2016: 1-11.

[20] Vici G, Belli L, Biondi M, Polzonetti V. Gluten free diet and nutrient deficiencies: A review. Clinical Nutrition. 2016; 35 (6): 1236-1241.

[21] Rashid M, Cranney A, Zarkadas M, Graham ID, Switzer C, Case S, Molloy M, Warren RE, Burrows V, Butzner JD. Celiac disease: evaluation of the diagnosis and dietary compliance in Canadian children. Pediatrics. 2005; 116(6):754-759.

[22] Errichiello S, Esposito O, Di Mase R, Camarca ME, Natale C, Limongelli MG, Marano C, Coruzzo A, Lombardo M, Strisciuglio P, Greco L. Celiac disease: predictors of compliance with a gluten-free diet in adolescents and young adults. Journal of Pediatric Gastroenterology and Nutrition. 2010; 50(1): 54-60.

[23] Roma E, Roubani A, Kolia E, Panayiotou J, Zellos A, Syriopoulou VP. Dietary compliance and life style of children with coeliac disease. Journal of Human Nutrition and Dietetics . 2010; 23(2): 176-82.

[24] Kurppa K, Lauronen O, Collin P, Ukkola A, Laurila K, Huhtala H, Mäki M, Kaukinen K. Factors associated with dietary adherence in celiac disease: a nationwide study. Digestion. 2012; 86(4): 309-14.

[25] Zarkadas M, Dubois S, MacIsaac K, Cantin I, Rashid M, Roberts KC, La Vieille S, Godefroy S, Pulido, OM. Living with coeliac disease and a gluten-free diet: a Canadian perspective. Journal of Human Nutrition and Dietetics. 2013; 26(1): 10-23.

[26] Samasca G, Sur G, Lupan I, Deleanu D. Gluten-free diet and quality of life in celiac disease. Gastroenterology and Hepatology from Bed to Bench. 2014; 7(3): 139-43.

[27] Samasca G, Lerner A, Sur G, Lupan L, Makovichy P, Matthias T, Freeman HJ. Challenging in Glute-free diet in celiac disease: Prague consensus. European Journal of Clinical Investigation. 2017.

[28] Real A, Comino I, Lorenzo L, Merchán F, Gil-Humanes J, Giménez AJ, López-Casado MA, Torres MI, Cebolla Á, Sousa C, Barro F, Pistón F. Molecular and Immunological Characyerization of Gluten Proteins Isolated from Oat Cultivars That Differ in Toxicity for Celiac Disease. PLOS ONE. 2012; 7(12): e48365.

[29] Comino I, Moreno ML, Real A, Rodríguez-Herrera A, Barro F, Sousa C. The Gluten-Free Diet: Testing Alternative Cereals Tolerated by Celiac Patients. Nutrients. 2013; 5: 4250-4268.

[30] Lerner A, Matthias. Changes in intestinal tight junction permeability associated with industrial food additives explain the riseng incidence of autoimmune disease. Autoimmunity Reviews. 2015; 14: 479-489.

[31] Hopman EGD, le Cessie S, von Blomberg BME, Mearin ML. Nutritional management of the gluten-free diet in young people with celiac disease in The Netherlands. Journal of Pediatric Gastroenterology and Nutrition. 2006; 43(1): 102-8.

[32] Zuccotti G, Fabiano V, Dilillo D, Picca M, Cravidi C, Brambilla P. Intakes of nutrients in Italian children with celiac disease and the role of commercially available gluten-free products. Journal of Human Nutrition and Dietetics. 2013; 26(5): 436-444.

[33] Brambilla P, Picca M, Dilillo D, Meneghin F, Cravidi C, Tischer MC, Vivaldo T, Bedogni G, Zuccotti GV. Changes of body mass index in celiac children on a gluten-free diet. Nutrition, Metabolism, and Cardiovascular Diseases. 2013; 23(3): 177-82.

[34] Barton SH, Kelly DG, Murray JA. Nutritional Deficiencies in Celiac Disease. Gastroenterology Clinics of North America. 2007; 36: 93-108.

[35] Venkatasubramani N, Telega G, Werlin SL. Obesity in pediatric celiac disease. Journal of Pediatric Gastroenterology Nutrition. 2010; 51: 295-297.

[36] Diamanti A, Capriati T, Basso MS, Panetta F, Laurora VMC, Bellucci F, Cristofori F, Francavilla R. Celiac Disease and Overweight in Children: An Update. Nutrients. 2014; 6: 207-220.
[37] Andrews D, Nonnecke B, Preece J. Electronic survey methodology: A case study in reaching hard to involve Internet Users. International Journal of Human-Computer Interaction. 2003; 16:185-210.

[38] Wright KB. Researching Internet-Based Populations: Advantages and Disadvantages of Online Survey Research, Online Questionnaire Authoring Software Packages and Web Survey Services. Journal of Computer-Mediated Communication. 2005; 10: 00-00.

[39] Nulty DD. The adequacy of response rates to online and paper surveys: what can be done?. Assessment \& Evaluation in Higher Education. 2008; 33: 301-314.

[40] Direção Geral de Saúde (DGS). Actualização das curvas de crescimento. 2006. Available: http://www.dgs.pt.

[41] Instituto Nacional de Saúde Doutor Ricardo Jorge (INSA). Tabela da Composição de Alimentos. 2010.

[42] Direção Geral de Saúde (DGS). Plataforma nacional contra a obesidade: Obesidade Infantil. 2015. Available: http://www.plataformacontraaobesidade.dgs.pt.

[43] World Health Organization (WHO) Human energy requirements. 2004.

[44] World Health Organization (WHO). European Guideline for children and young people (7-18 years). 2006.

[45] Whitley E Ball J. Statistics review 6: Nonparametric methods. BioMed Central Ltd. 2002. Online at http://ccforum.com/content/6/6/509.

[46] Husby S, Koletzko S, Korponay-Szabó IR, Mearin ML, Phillips A, Shamir R, Troncone R, Giersiepen K, Branski D., Catassi C, Lelgeman M., Mäki, Ribes-Koninckx C, Ventura A, Zimmer KP. European Society for Pediatric Gastroenterology, Hepatology, and Nutrition Guidelines for the Diagnosis of Coeliac Disease. Journal of Pediatric Gastroenterology \& Nutrition. 2012; 54 (1): 136-160.

[47] Ivarsson A, Persson LÅ, Nyström L, Hernell O. The Swedish coeliac disease epidemic with a prevailing twofold higher risk in girls to boys may reflect gender specific risk factors. European Journal of Epidemiology: 2003; 18: 677-84.

[48] Öhlund K, Olsson C, Hernell O, Öhlund I. Dietary shortcomings in children on a gluten-free diet. Journal of Human Nutrition and Dietetics. The Official Journal of the British Dietetic Association. 2010; 23(3): 294-300.

[49] Barera G, Mora S, Brambilla P, Ricotti A, Menni L, Beccio S, Bianchi C. Body composition in children with celiac disease and the effects of a gluten-free diet: a prospective case-control study. The American Journal of Clinical Nutrition. 2000; 72(1): 71-5.

[50] Niewinski M. Advances in Celiac Disease and Gluten-Free Diet. Journal of the American Dietetic Association. 2008: 661-672.

[51] Penagini F, Dilillo D, Meneghin F, Mameli C, Fabiano V, Zuccotti GV. Gluten-Free Diet in Children: Ana Approach to a Nutritionally Adequate and Balanced Diet. Nutrients, 2013; 5: 4553-4565.

[52] Reilly NR, Aguilar K, Hassid BG, Cheng J, Defelice, AR, Kazlow $\mathrm{P}$, Bhagat G, Green PH. Celiac disease in normal-weight and overweight children: clinical features and growth outcomes following a gluten-free diet. Journal of Pediatric Gastroenterology and Nutrition. 2011; 53(5): 528-31.

[53] Dickey W, Kearney N. Overweight in celiac disease: Prevalence, clinical characteristics, and effect of a gluten-free diet. American Journal of Gastroenterology. 2006; 101: 2356-2359.

[54] Ferrara P, Cicala M, Tiberi E, Spadaccio C, Marcella L, Gatto A, Calzolari P, Castellucci G. High fat consumption in children with celiac disease. Acta GastroEnterologica Belgium. 2009; 72(3): 296-300.

[55] Martin J, Geisel T, Maresch C, Krieger K, Stein J. Inadequate nutrient intake in patients with celiac disease: results from a german dietary survey. Digestion. 2013; 87: 240-246.

[56] Jasthi B, Stevenson J, Harnack L. Comparation of nutrient composition of gluten-containing and gluten-free sliced breads and sparghetti noodles. $38^{\text {th }}$ National nutrient databanck conference, Portland (USA). 2014

[57] Lee AR, Ng DL, Dave E, Ciaccio EL, Green PHR. The effect of substituting alternative grains in the diet on the nutritional profile of the gluten-free diet. Journal of Human Nutrition and Dietetics. 2009; 22: 359-363.

[58] Wild D, Robins GG, Burley VJ, Howdle PD. Evidence of high sugar intake, and low fibre and mineral intake, in the gluten-free diet. Alimentary Pharmacology and Therapeutics. 2010; 32: 573-581. 
[59] Shepherd SJ, Gibson PR. Nutritional inadequacies of the glutenfree diet in both recently-diagnosed and long-term patients with coeliac disease. Journal of Human Nutrition and Dietetics. 2013; 26(4): 349-358.

[60] Castillo-Duran C, Pacheco-Acosta J. New Insights into Celiac Disease and Micronutrient Deficiencies in Pediatrics. International Journal of Celiac Disease. 2014; 2 (4): 119-20.
[61] Miranda J, Lasa A, Bustamante MA, Churruca I, Simon E. Nutritional Differences Between a Gluten-free Diet and a Diet Containing Equivalent Products with Gluten. Plant Foods Human Nutrition. 2014; 69: 182-187.

[62] Afonso D, Jorge R, Moreira AC. Alimentos Com e Sem Glúten Análise Comparativa de Preços de Mercado. [Gluten and GlutenFree Products - Price Difference]. Acta Portuguesa de Nutrição. 2016: 10-16. 